\title{
Effects of Bitter Cola (Garcinia Kola) On Haemostatic and Biochemical Indiced Male Diabetic Albino Wistar Rats.
}

\author{
Ofor C.C,Oguwike F N, Onubueze D.P.M, Olisa M.C. \\ Department of medical Biochemistry. Faculty of Basic medical sciences, Anambra state University Uli, \\ Anambra state. \\ Department of Physiology, Faculty of Basic medical sciences Anambra state University Uli Anambra state \\ Nigeria. \\ Department of Community Medicine, Anambra state University Teaching Hospital Amaku, Anambra state.
}

\begin{abstract}
The effects of Bitter cola (Garcinia cola) on haemostatic and biochemical indices of induced male diabetic albino wistar rats were investigated 21 male albino rats (200-230g) were placed into three groups namely Group A (control) Group B (induced diabetic rats on bitter cola extract) and Group C (induced diabetic rats on dianil reference tablets). At the end of the 28 days feeding on the extracts, blood samples were withdrawn from the animals for investigation. The results from the haemoglobin concentration and packed cell volume indicates a reduction in control rats compared with test rats; Hb Group A 13.8g/dl, group B 10.8g/dl, group C 13.5g/dl, PCV group A 41\%, group B 31\% group C 41\%. The white blood cell count and platelet count

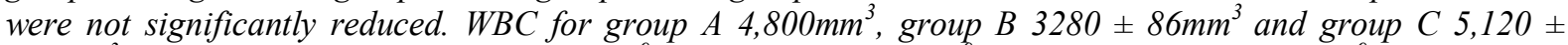
$666 \mathrm{~mm}^{3}$. Platelet count group A $216 \pm 40 \times 10^{9} / \mathrm{l}$, group $B 160 \pm 70 \times 10^{9} / \mathrm{l}$, and group $C 210 \pm 57 \times 10^{9} /$.

On the haemostatic indices there is no effect. The prothrombin time for group A 13.0 $\pm 2.1 \mathrm{sec}$, group $B$ $12.8 \pm 0.5 \mathrm{sec}$ and group C $13.58 \pm 0.3 \mathrm{sec}$. The bleeding time and clotting were not also affected in the study. On biochemical analysis, the rats fed with Garcinia kola demonstrated a lowering in the Fasting blood sugar with value in control rats (group A) 75 2.6 , group B (on extracts) $56.3 \pm 3.8 \mathrm{mg} / \mathrm{dl}$ and group C $69.8 \pm 0.8 \mathrm{mg} / \mathrm{dl}$

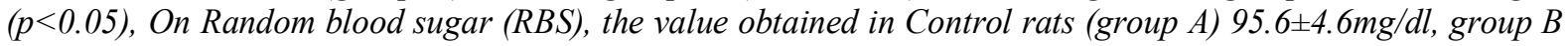
$68.3 \pm 0.2 \mathrm{mg} / \mathrm{dl}$ and group $C$ (on dianil tabs) $72.3 \pm 0.4 \mathrm{mg} / \mathrm{dl}(p<0.05$ ). There is a reduction on urine output in the animals on bitter cola extract (group B) compared to the Control rats (group A) $p<0.05$. The values were obtained as $5.16 \pm 0.2 \mathrm{ml}$ in Control rats, $2.16 \pm 0.29 \mathrm{ml}$ in group B rats, $1.96 \pm 0.11 \mathrm{ml}$ in group C respectively. It can be deduced from this investigation that Garcinia cola contains some active principles interfering with insulin metabolism causing reduction in glucose level.
\end{abstract}

Key Words: Diabetes, Bitter cola, Haemostatic, Albino rats, Biochemical, Bleeding time, Prothrombin.

\section{Introduction}

From Neolithic time, some plants have been discovered to have medicinal value (Olaleye et al, 2000). These plants have been used as a source of virus drugs where man can get a cure for almost all aliments. This have been made easy by the use of recently developed photochemical and phytopharmacological techniques. Substances called active principles have been implicated by extraction from these natural herbs. These active principle are mostly phytochemicals like alkaloids. The ability of this plant to cure different aliments have been traced to these essential/active principles (Ukairo et al 2001).

Diabetes mellitus (DM) is a metabolic disease that involves problems with the hormone insulin. It is characterized by hyperglycemia, glycosuria, increased protein breakdown, polyuria, weightloss, ketosis, acidosis and coma. This pathological condition can lead to a life-threatening rise in the blood levels of the ketone bodies (Berg et al, 2002). Treatment of patients is based on the axis of control or management than total cure. Some herbs have been screened to show that they have some hypoglycermia effects in both normal and diabetic animals. One of such herbs is Garcinia cola. Crude extracts of some plants could play roles in hastening the haemostatic activities in a damaged tissue or vessels when applied topically on the wound or cut to arrest bleeding and hasten healing of wound (Oguwike et al, 2009). Garcinia cola, Heckel (Gultiferae), a largely cultivated forest tree indigenious to sub-saharan Africa has been referred to as the "wonder plant" because almost every part of it has been found to be of medical importance to the ethnomedical practitioners.

The seed commonly known as bitter cola male kola or false kola is a masticatory used in traditional hospitality, cultural and social ceremonies. Extraction of the plant has been traditionally used for aliment such as laryngitis, liver diseases and cough. The seeds are used to prevent or relieve colic, cure head or chest colds and relieve cough (Iwu et al, 1993). The seed also has anti-inflammatory, antimicrobial, antidiabetic and antiviral (Iwu etal, 1985) as well as antiulcer properties (Ibironke et al, 1997). 


\title{
Chemical Contents Of Garcinia Kola:
}

Though the plant has a traditional name in Nigeria called "Akilu, agbilu" in Igbo language, "efiari" by the Efiks of Southern Cross River state in Nigeria contains some chemical such as sterols, terpenoids, flavenoids, glycosides, pseutannins, saponin, protein and starch.

Most times ethnomedical practitioners administer this plant extract being ignorant of the effect it may have in human body hence this research is aimed at; the effectiveness of Bitter cola in lowering blood sugar in diabetics wister rat to know if there is any haemostatic element present in the extract and to know its effect on haematological profile of albino wister rat. The fruit of bitter cola is a reasonable source of ascorbic acid. The pericarp mesocarp contains a high percentage of ascorbic acid. The edible mesocarp is rich in microelements including nitrogen, potassium, phosphorus, magnesium and calcium. The pericarp (peel) has higher amount of mineral elements except nitrogen and phosphorous. Only a trace of chromium is found. Other toxic acids such as tannins, phytic and hydrocynic acids are low in the pericarp and mesocarp of bitter cola (Eka, 1984). Other constituent include Ash, crude protein, crude fiber, crude lipid, water soluble oxalate, terpenoids, and fat (Anicher and Uwakwe, 1990).

\section{Materials And Methods:}

The phytochemical analysis for the constituents of the plant extract and the $\mathrm{LD}_{50}$ of the extract were studied before the haematological haemostatic and biochemical experiments were done.

\begin{abstract}
ANIMALS :
Twenty one only healthy albino rats weighing $200-230 \mathrm{~g}$ were sealed for the study. The rats were housed in wire mesh cages under standard conditions (temperature $22-25^{\circ} \mathrm{c}$, 12 hour light and 12 hour darkness cycle). They were allowed free access to water and feed (produced by Pfizer Nigeria limited Benin Edo state), through the period of experiments. Generally the study was conducted in accordance with the recommendation from the declaration of Helsink, on guiding principles in care and use of animals.
\end{abstract}

\section{EXPERIMENTAL DESIGN:}

The animals were randomly assigned into three group of 7 rats each. Group A served as control served with only rat feed and drinking water ad libitum. Group B served as induced diabetic rats on Bitter cola extract and rat feed while Group C served as induced diabetic rats on Dianil tablets and rat feed. They were placed on acute feeding on the extract for 28 days.

\section{PREPARATION OF EXTRACT OF GARCINIA KOLA}

Fresh fruits of Bitter cola was bought from Umuezealaeze local market and the species was identified by a taxonomist. They were weighed, washed and spread in the sun for two weeks to dry. They were further oven dried. On drying, it was milled to power and stored in a dry environment.2 gram of the extract was dissolved in $100 \mathrm{ml}$ of distilled water (using the method of Harbourne, 1973, Trease and Evans 1996)to give 20mg and stored under $4^{0} \mathrm{c}$ to minimize the activity of micro organism. $1.0 \mathrm{ml}$ was administered daily to each of the rats using blunt syringe for 28 day. The control group received clean water instead of extract.

\section{PHYTOCHEMICAL ANALYSIS OF FRUITS:}

The aqueous extract of the fruits of Garcinia kola was screened for the presence or absence of various secondary metabolites using standard phytochemical screening procedures as described by Harbourne (1973), Trease and Evans(1996). The extract was tested for Glycosides, saponins, calcium, resins, alkaloids, flavenoids, reducing, sugars, carbohydrates, steriods, acidic compounds, fat and oils.

\section{TOXICITY STUDY:}

The $\mathrm{LD}_{50}$ of extract in albino rats was determined using Lorke's method (1983). The procedure of determining the lethal dose is by increasing the concentration of the extracts administered to the rats (per body weight) in each group consisting of eight (8) rats per group for five days. The concentration used are $500 \mathrm{mg} / \mathrm{kg}$, $1000 \mathrm{mg} / \mathrm{kg}, 1,500 \mathrm{mg} / \mathrm{kg}, 2000 \mathrm{mg} / \mathrm{kg}, 3,000 \mathrm{mg} / \mathrm{kg}, 4,000 \mathrm{mg} / \mathrm{kg}$ and $5,000 \mathrm{mg} / \mathrm{kg}$ respectively. The mortality rate was determined and a graph plotted to determine the $\mathrm{LD}_{50}$.

\section{INDUCTION OF DIABETES (HYPERGLYCEMIA) IN RATS:}

Diabetes was induced in male wister albino rats by intraperitoneal administration of alloxan monohydrate $(150 \mathrm{mg} / \mathrm{kg}$ body weight) dissolved in normal saline given at the rate of $0.4 \mathrm{ml}$ at $48 \mathrm{hrs}$ intervals. The rats were fasted for $18 \mathrm{hrs}$ before the first injection. Since alloxan is capable of producing fatal hypoglycemia as a result of massive pancreatic insulin release, the rats was treated with 30 percent glucose solution orally at different time intervals after six hours of alloxan induction and 5 percent glucose solution was 
kept in bottles in their cages for the next $24 \mathrm{hrs}$ to prevent hypoglycemia. After 7 days, the rats with diabetes mellitus showing glycosuria (indicated by urinalysis and B.G meter) and hyperglycemia with glucose range of $250 \mathrm{mg}$ to $350 \mathrm{mg} / \mathrm{dl}$ were used for the test. Induction of diabetics was accomplished by three doses of alloxan that was administered at third injection, the rats were fasted again and the blood glucose levels were recorded.

\section{ORAL ADMINISTRATION OF THE AQUEOUS EXTRACT:}

Water of extract of Garcinia kola was administered to the test rats using $1.0 \mathrm{ml}$ syringe. The control rats received clean water. Rat feed was given to all the rats and water ad libitum. The aqueous extract was administered to the test rats (Group B only) with a blunt needle and syringes while group c rats was administered with dianil tablet dissolved in injection water. Extract feed lasted for 28 days.

\section{DETERMINATION OF HAEMOSTATIC AND BIOCHEMICAL PROFILES:}

$2.0 \mathrm{ml}$ of blood samples were collected into EDTA sequestrene and sodium citrate bottles. They were used within hours of sample collection. Those collected in sodium citrate bottles were spun and the plasmas was separated and used for determination of prothrombin time. Blood samples were collected before the extract feed and 28 days before the extract feed. The packed cell volume was determined according to the haematocrit method described by Alexander and Griffits (1993). The haemoglobin concentration was estimated according to the method described by Alexander and Griffit (1993). The white blood cell count and platelet counts were estimated according to the visual method of Dacie and Lexis (1991). The whole blood clotting time and the bleeding time were carried out by methods of Dejena et al 1982. The prothrombin time was carried out by the method of Quick's one stage method as described in Baker (1985). The fasting blood sugar and Random blood sugar test were carried out using B.G meter.

The fasting blood sugar test was carried out with animals in Group B and C after 12hrs overnight fast, sample was collected from them before giving them their feed and after eating, around 30mins interval, the Random blood sample was collected from them for sugar test.

\section{STATISTICAL ANALYSIS:}

The data obtained from the study were expressed as mean and standard deviation (mean + S.D) while student s'-T-test was used to compare the result of the control and the test. A P-value of less than or equivalent to $(\mathrm{p}<0.05)$ or $\mathrm{p}=0.05)$ was considered statistically significant.

\section{Result:}

Table 1: Phytochemical analysis of Garcinia kola.

\begin{tabular}{|l|l|l|l|l|c|l|}
\hline \multicolumn{7}{|c|}{ CONSTITUNTS IN EXTRACT OF GARCINIA KOLA } \\
\hline $\begin{array}{l}\text { Calcium, } \\
\text { Alkaloids, } \\
\begin{array}{l}\text { Carbohydrate } \\
\mathrm{s}\end{array}\end{array}$ & $\begin{array}{l}\text { Saponin } \\
\mathrm{s}\end{array}$ & $\begin{array}{l}\text { Flavenoi } \\
\mathrm{ds}\end{array}$ & $\begin{array}{l}\text { Glycosid } \\
\text { es }\end{array}$ & $\begin{array}{l}\text { Reducing } \\
\text { Sugar }\end{array}$ & Steroids & $\begin{array}{l}\text { Tanins, } \\
\text { Resins, } \\
\text { Terpenoids, } \\
\text { Fats and } \\
\text { Oils. }\end{array}$ \\
\hline \multicolumn{1}{|c|}{+++} & ++ & ++ & ++ & ++ & - & \\
\hline
\end{tabular}

1. Negative (absent)

+ Present in small concentration

++ present in moderately high concentrations.

+++ Present in very high concentrations.

Table 2: Indicates the effect of Garcinia kola on full blood count (FBC) and platelet count of induced male diabetic rats and their controls.

\begin{tabular}{|c|c|c|c|c|c|}
\hline Groups & $\mathrm{Hbg} / \mathrm{dl} \pm \mathrm{S} . \mathrm{D}$ & PCV $\% \pm$ S.D & $\mathrm{WBC} / \mathrm{mm}^{3} \pm \mathrm{S} . \mathrm{D}$ & $\begin{array}{l}\text { Platelets } \times 10^{9} / 1 \pm \\
\text { S.D }\end{array}$ & P-Value \\
\hline $\begin{array}{l}\text { Group A (control) } n=7 \\
\text { (extract free). }\end{array}$ & $13.8 \pm 3.16$ & $41 \pm 4.60$ & $5,360 \pm 290$ & $216 \pm 40$ & - \\
\hline $\begin{array}{l}\text { Test rats. Group } \mathrm{B} \mathrm{n}=7 \\
\text { Day } 1 \text { before induction } \\
\text { of Diabetes. }\end{array}$ & $13.5 \pm 2.84$ & $40.6 \pm 0.43$ & $4,864 \pm 164$ & $220 \pm 57$ & - \\
\hline $\begin{array}{l}\text { GroupB: Diabetic rats } \\
30 \text { days after extract } \\
\text { feed. }\end{array}$ & $10.4 \pm 2.04$ & $31 \pm 2.69$ & $3,280 \pm 86$ & $160 \pm 70$ & $\mathrm{P}<0.05$ \\
\hline $\begin{array}{l}\text { Group } \mathrm{C}, \mathrm{n}=7 \text { Day } 1 \\
\text { before induction of } \\
\text { diabetes. }\end{array}$ & $13.6 \pm 2.73$ & $41 \pm 4.2$ & $5,128 \pm 763$ & $200 \pm 61$ & - \\
\hline $\begin{array}{l}\text { Group C: Diabetic rats } \\
5 \text { days after dianil tabs. }\end{array}$ & $13.5 \pm 0.8$ & $41 \pm 1.7$ & $5,120 \pm 666$ & $210 \pm 57$ & $\mathrm{p}>0.05$ \\
\hline
\end{tabular}


Table 3: shows the effects of Garcinia kola on the haemostatic indices of induced male diabetic rats and their corresponding controls.

\begin{tabular}{|l|l|l|l|c|}
\hline GROUPS & $\begin{array}{l}\text { Prothrombin time sec } \pm \\
\text { S.D }\end{array}$ & $\begin{array}{l}\text { Bleeding time mins } \pm \\
\text { S.D }\end{array}$ & Clotting time sec \pm S.D & P-Value \\
\hline $\begin{array}{l}\text { Group A, } \mathrm{n}=7 \text { (control) } \\
\text { Extract free }\end{array}$ & $13 \pm 2.6$ & $2.5 \pm 0.45$ & $5.1 \pm 0.62$ & - \\
\hline $\begin{array}{l}\text { Test rats Group B, } \mathrm{n}=7 \\
\text { Day 1 before Diabetes } \\
\text { induction }\end{array}$ & $13.2 \pm 1.4$ & $2.6 \pm 0.31$ & $5.6 \pm 0.48$ & - \\
\hline $\begin{array}{l}\text { Group B: Diabetic rats } \\
\text { 30 days after Garcinia } \\
\text { kola } \text { extract. }\end{array}$ & $12.8 \pm 1.2$ & 2.570 .24 & $5.0 \pm 1.36$ & $\mathrm{p}>0.05$ \\
\hline $\begin{array}{l}\text { Group C, } \mathrm{n}=7 \text { Day 1 } \\
\text { before Diabetes } \\
\text { induction }\end{array}$ & $13.4 \pm 1.73$ & $2.38 \pm 0.36$ & $5.9 \pm 1.42$ & - \\
\hline $\begin{array}{l}\text { Group C: Diabetic rats } \\
\text { days after dianil tabs. }\end{array}$ & $13.0 \pm 0.68$ & $2.40 \pm 0.15$ & $5.7 \pm 0.32$ & $\mathrm{p}>0.05$ \\
\hline
\end{tabular}

Table 4: Biochemical indices and urine output of diabetic male albino rats on extract feed of Garcinia kola and their corresponding controls.

\begin{tabular}{|l|l|l|l|r|}
\hline Groups. & $\begin{array}{l}\text { FBS mg/dl } \\
\pm \text { S.D }\end{array}$ & $\begin{array}{l}\text { RBS mg/dl } \pm \\
\text { S.D }\end{array}$ & $\begin{array}{l}\text { Urine volume } \\
\text { ml/S.D }\end{array}$ & P-value \\
\hline $\begin{array}{l}\text { Group A, n=7 (control) } \\
\text { Extract free. }\end{array}$ & $75 \pm 2.6$ & $95 \pm 4.6$ & $5.0 \pm 0.2$ & - \\
\hline $\begin{array}{l}\text { Test rats Group B, n=7 } \\
\text { Day 1 before diabetes } \\
\text { induction. }\end{array}$ & $81 \pm 4.3$ & $94 \pm 0.19$ & $5.2 \pm 0.8$ & - \\
\hline $\begin{array}{l}\text { Group B: Diabetic rats 30 } \\
\text { days after Garcinia kola } \\
\text { extract }\end{array}$ & $56 \pm 3.7$ & $68 \pm 0.2$ & $2.56 \pm 0.29$ & $\mathrm{P}<0.05$ \\
\hline $\begin{array}{l}\text { Group C, n=7 Day 1 } \\
\text { before diabetes induction }\end{array}$ & $79.4 \pm 3.1$ & $92 \pm 1.8$ & $5.0 \pm 1.4$ & - \\
\hline $\begin{array}{l}\text { Group C diabetic rats 5 } \\
\text { days after dianil tabs. }\end{array}$ & $69.8 \pm 0.8$ & $72.3 \pm 0.4$ & $1.96 \pm 0.11$ & $\mathrm{P}<0.05$ \\
\hline
\end{tabular}

Figure 1: Lethality study $\left(\mathrm{LD}_{50}\right)$ the effects of administering graded doses of $(1000-5000 \mathrm{mg} / \mathrm{kg}$ IP rat) of the Garcinia kola against the percentage mortality.

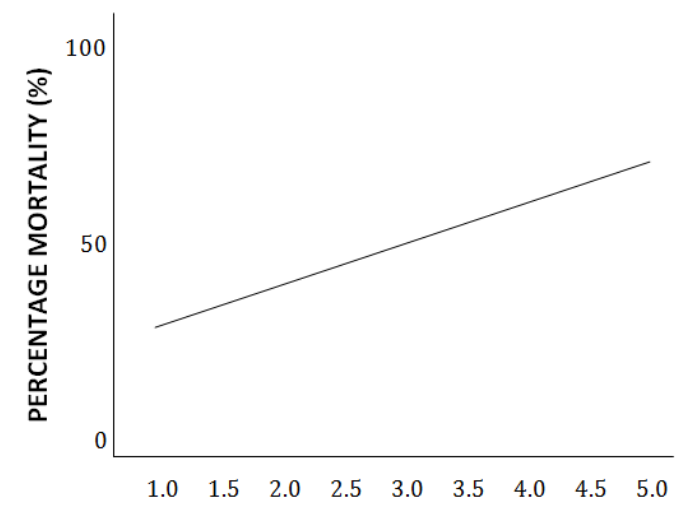

\section{Discussion:}

The effect of Garcinia kola on the haemostatic mechanism and biochemical profile has been analyzed. Toxicity may affect the result of this study and so acute toxicity studies using LD $_{50}$ were carried out before the extract was given to the animals. The result of lethality studies shows that the $\mathrm{LD}_{50}$ in rats using Garcinia kola is $2,000 \mathrm{mg} / \mathrm{kg}$ (f.g1.). hence the volume $(1 \mathrm{ml})$ containing $5 \mathrm{mg} / \mathrm{kg}$ concentration of the extract was safe throughout the period of study. The phytochemical studies shows that the extract contains some elements that could stimulate glucose utilization like chloropemide to brings its hypoglycaemic effect in the mammalian experimental animals used. There is a significant lowering of blood sugar $(\mathrm{p}<0.05)$ in Group B rats subjected to water extract of Garcinia kola which is indicative of hyperglycemia. There is also a decrease in haemoglobin concentration, packed cell volume $(\mathrm{p}<0.05)$ in the group $\mathrm{b}$ rats. This could be as a result of poor appetite caused 
in the rats due to the bitter elements in Garcinia kola. Reduction in haemoglobin concentration could lead to anaemia.

Results obtained in the haemostatic study shows that Garcinia kola contains element that could react with calcium to cause shortening in bleeding and clotting times $(\mathrm{p}<0.05)$ as indicated in table 3 .

Garcinia kola has the ability to reduce urine volume in diabetic rats as shown in table $3, p<0.05$. This could be attributed to the fact that the extract contain some elements that could concentrate urine and reduce polydipsia in diabetic rats.

It could be deduced from this work that Garcinia kola contains some elements that help to repair pancreas (Oguntola 2013) and bring high blood glucose to normal.

\section{References}

[1]. ALLEXANDER R.R and GRIFFITHS J.M (1993). Haematocrit in: Basic Biochemical methods $2^{\text {nd }}$ Ed John Willey and Sons inc. Publications New York pp 186-187.

[2]. ANICHE G.NN and UWAKWE G.U (1990). Potential use of Garcinia kola as s hop substitute in Lager beer brewing. World J. icrobial Biotechnology 6:323-486.

[3]. BAKER F.J (1985). Investigation for haemostatic abnormalities. Introduction to Medical Laboratory Technologu. Butterworths publications. Woburn London p343.

[4]. BERG J.M, TYMOCZKO J.L, STRYER L (2002). Biochemistry $5^{\text {th }}$ ed (international edition) W.H Freeman and company, New York Pp 616.

[5]. B.G METER and STRIPS manufactured in Taiwan. Manufactured for FGICO (First Gulf International inc). 3055 Sage road, No 210 Houston Texas. 77056 USA. www.fgico.com.

[6]. DACIE J.K and LEWIS S.M (1991). Practical Haematology Lon don, Churchill Living stone Pp 566.

[7]. DEJANA E, VILLA S, deGALATANO G (1982). Bleeding time of rats. A comparison of recent experimental conditions. Thromb. Haemostat 48:108-111.

[8]. EKA O.U (1984). Studies in the feasibility of replacing hop by other bittering substances in Brewing. Nig. J. Microbial 4(1-2), 128133 .

[9]. HARBOURNE C.B.C (1973). Phytochemical method Channan and Hall, London p 279.

[10]. IBIRONKE G.F, OLALEYE S.B, BALOGUN O and AREMU D.A (1997). Antiulcerogenic effect of Phytotherapy Research 11:312-313.

[11]. IWU M.M (1986). Plant flanoids in Biology and Medicine. V cody, E Middleton and J.B Harborne eds. Ala R. Liss, New York pp 485 .

[12]. IWU M.M (1993). Pharmacognotical Profile of selected Medicinal plants. In: Handbook of African Medicinal plants. CRC press, Boca Raton, Florida pp 183.

[13]. OGUNTOLA S (2013). Things Bitter Leaf can do. Nigerian Tribune.com.ng/news 2013/index----/15271.things-bitter-leaf-candohtml.

[14]. OGUWIKE F.N, NNELI R.O, OSIM E.E (2009). Evaluation of effects of Musa paradisiacal (plantain) extract on the haemostatic Mechanism of albino Wistar rats. Journal of Biochemical Sciences in Africa Vol 7 No 1\&2 ISSN No. 1597-216k Pp 31-38.

[15]. OLALEYE S.B, FAROMBI E.O, ADEWOYE E.A, OWOYELE B.V, ONASANWO S.A and ELEGBA R.A (2000). Analgesic and anti-inflammatory effects of kolaviron (A Garcinia kola seed extract) Afr. J. Biomed.Res 3:171-174.

[16]. TREASE G.E and EVANS W.C (1996). Textbook of Pharmacognosy $14^{\text {th }}$ Ed. W.B Saunders. London $p 11$.

[17]. UKAIRO J.K (2001): The effect of aquoes extract of Nchanwu (Ocimum viride) on serum glucose, alanin and Aspartate amino transferases level of alloxan induced albino rats. B.Sc Thesis Abia state University Uturu Nigeria. 